\title{
HÅLLBARARE TEXTILIER PÅ SJUKHUS
}

Guide till hållbar upphandling

i hälso- och sjukvårdssektorn

(1) Nordiska ministerrådet 
Hållbarare textilier på sjukhus

Guide till hållbar upphandling i hälso- och sjukvårdssektorn

David Watson, PlanMiljø

Rikke Fisher-Bogason; PlanMiljø

ISBN 978-92-893-5052-5 (PRINT)

ISBN 978-92-893-5053-2 (PDF)

ISBN 978-92-893-5054-9 (EPUB)

http://dx.doi.org/10.6027/ANP2017-739

ANP 2017:739

(c) Nordiska ministerrådet 2017

Layout: Gitte Wejnold

Coverphoto: Pexels.com

Photos: Scanpix.dk

www.norden.org/nordpub

\section{Det nordiska samarbetet}

Det nordiska samarbetet är ett av världens mest omfattande regionala samarbeten. Det omfattar Danmark, Finland, Island, Norge och Sverige samt Färöarna, Grönland och Åland.

Det nordiska samarbetet är politiskt, ekonomiskt och kulturellt förankrat och en viktig del av euro-peiskt och internationellt samarbete. Den nordiska gemenskapen arbetar för ett starkt Norden i ett starkt Europa.

Det nordiska samarbetet vill styrka nordiska och regionala intressen och värderingar i en global omvärld. Gemensamma värderingar länderna emellan bidrar till att stärka Nordens ställning som en av världens mest innovativa och konkurrenskraftiga regioner.

Nordiska ministerrådet

Ved Stranden 18

DK-1061 København K

www.norden.org 


\section{HÅLLBARARE TEXTILIER PÅ SJUKHUS}

Guide till hållbar upphandling i hälso- och sjukvårdssektorn 


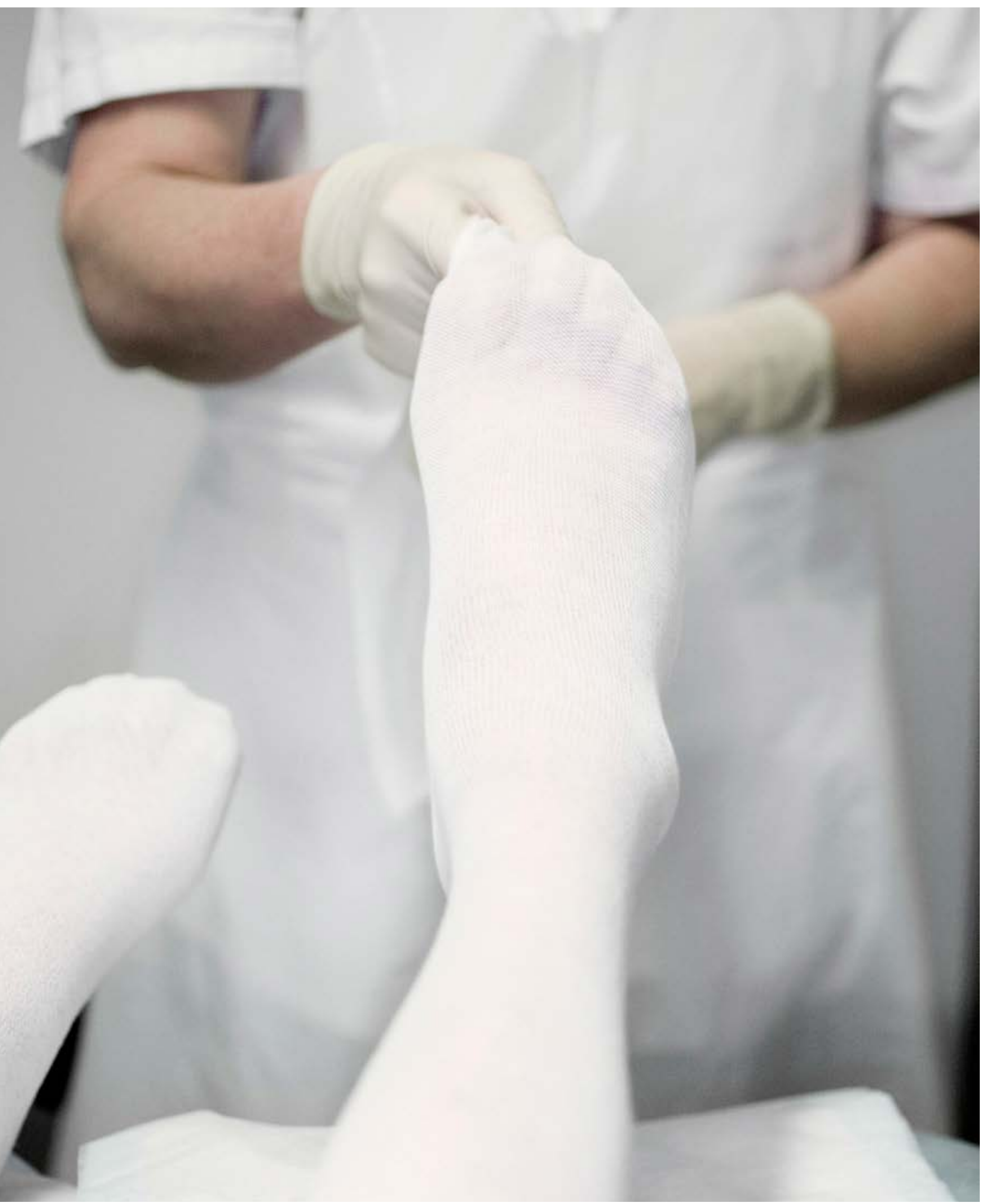




\section{INNEHÅLL}

6 Så här använder du guiden

8 Avsnitt 1

De viktigaste aspekterna att ta hänsyn till

10 Avsnitt 2

Upphandlingsprocessen, marknadsdialog och innovation

15 Avsnitt 3

Länkar till användbara dokument och resurser

22 Avsnitt 4

En kort genomgång av miljömärkningarna

24 Avsnitt 5

Välja fiber

28 Avsnitt 6

Engångstextilier jämfört med flergångstextilier

30 Avsnitt 7

Tillämpa den totala ägandekostnaden som parameter

33 Avsnitt 8

Om guiden och nätverket bakom 


\section{Så här använder du guiden}

Den här guiden riktar sig till upphandlare i hälso- och sjukvårdssektorn som planerar att upphandla textilprodukter och textilservicetjänster. Guiden hjälper dig att sammanställa rimliga och genomförbara miljökriterier och ger bakgrundsinformation för de aspekter som är viktigast att tänka på när du vill bidra till att minska miljöpåverkan från textilanvändningen.

Vägledningsdokument kan vara till stor hjälp för att hjälpa och inspirera upphandlare att förstå potentialen för miljömässiga och sociala förbättringar via offentliga inköp. I den här guiden kan du lära dig mer om miljökonsekvenserna av textilinköp, om olika miljömärkningar, vilka redan färdiga kriterier som finns att använda och vilka aspekter av textillivscykeln som är viktiga att ta hänsyn till. Det är dock viktigt att varje upphandling tar hänsyn till den specifika organisationens förutsättningar genom att upphandlaren i dialog med verksamheten beaktar alla organisatoriska och användarrelaterade effekter av de val som görs när kriterierna fastställs.

Hygienfaktorer och användarkomforten har alltid högsta prioritet i beslut som rör textilier i hälso- och sjukvårdssektorn. Det är möjligt att ta hänsyn till dessa två frågor och samtidigt minska miljöpåverkan. 


\section{DET KOMPLEXA UPPHANDLINGSOMRÅDET}

Det finns många olika modeller för upphandling av textilier för hälso- och sjukvårdssektorn i de nordiska länderna. De kan skilja sig åt beträffande hur upphandlingen organiseras och vad som upphandlas.

\section{- Hur organiseras upphandling?}

Detta är en komplex fråga och varierar från land till land och i vissa fall från region till region. I Danmark tecknar regionerna ramavtal för upphandling som enskilda sjukhus använder för att göra dagliga beställningar. I Norge samordnar en central upphandlingsorganisation ramavtalför upphandling som enskilda sjukhusstiftelser kan besluta sig för att använda eller göra egna upphandlingar. I Sverige tillämpas en ad hoc-struktur där regioner/landsting i vissa fall samarbetar för att upprätta ramavtal för upphandling och där enskilda sjukhus lägger mindre order. I allmänhet minskar ramavtal byråkratin och de resurser som krävs för att ta fram upphandlingsdokument och kan bidra till lägre priser på grund av stora volymer.

\section{- Vad är det som upphandlas?}

Ett typiskt ramavtal omfattar många tiotals om inte hundratals textilprodukter, från sängkläder och patientkläder till arbetskläder och operationssalstextilier. Regioner och sjukhusstiftelser kan dessutom, eller som alternativ, upphandla textil eller tvättservice. I synnerhet tvättservice upphandlas ofta av enskilda sjukhus eller grupper av sjukhus som är kopplade till ett tvätteri, snarare än på regional eller statlig nivå. Tvätterier kan vara privatägda, ägas av sjukhusstiftelsen, men med autonom budget, eller vara offentligt ägda genom ett partnerskap mellan sjukhus och lokala myndigheter. 
Avsnitt 1

\title{
De viktigaste aspekterna att ta hänsyn till
}

\author{
Textilkonsumtionen står för 4-6 \% av den totala miljöpåverkan som orsakas av \\ den europeiska konsumtionen'. Dessa effekter uppstår både under produktionen \\ av textilierna och under användningstiden. För hälso- och sjukvårdstextilier som \\ används flera gånger ligger vikten mer mot användningsfasen, medan den för \\ engångstextilier ligger mer mot produktionsfasen.
}

Denna handledning fokuserar på miljöanpassad upphandling, det vill säga hur upphandlare inom hälsooch sjukvård kan minska miljöeffekterna av sina inköp. Upphandlare kan dock också vara intresserade av att inkludera sociala hänsyn kopplade till anskaffning av produkter. I rutan på sidan 18 hittar du resurser som kan vara till hjälp för att ta fram kriterier för sociala hänsyn.

För att minska miljöpåverkan är det en bra idé att fokusera på båda områdena, både på valet av textilier för inköp/hyra och på hur de tvättas (även om du kanske inte har inflytande över det sistnämnda). Det är också viktigt att vara medveten om kopplingarna mellan dessa frågor. Olika fibertyper kan kräva olika behandling.

Du kan ta hänsyn till båda dessa frågor oberoende av om ni köper och äger textilierna och köper tvättservice eller upphandlar kompletta textiltjänster som omfattar en hyrmodell.

\section{Produktionsbaserade effekter: Många} produktionseffekter orsakas av användning av kemikalier och energi under tillverkning. Dessutom kan rester av vissa av de många farliga kemikalier som används under produktionen stanna kvar $\mathrm{i}$ textilprodukterna och utgöra en hälsorisk för känsliga användare.
Dessa frågor hanteras på ett bra sätt av olika miljömärkningar, särskilt den nordiska Svanenmärkningen och EU Ecolabel (även känd som EU-blomman) (se avsnitt 4, sidan 22) och med EU:s EU-GPP-kriterier (kriterier för miljöanpassad offentlig upphandling) för textilier. De beaktas även i olika nationella guider för miljöanpassad offentlig upphandling (se avsnitt 3, sidan 19).

Valet av fibertyp är också viktigt: bomullsproduktion har stor miljöpåverkan, främst till följd av den höga användningen av bekämpningsmedel, mark och vatten. Att välja ekologiska produkter minskar vissa av dessa effekter, men ett annat alternativ är att byta till andra fibrer som polyester. Du kan läsa mer om detta i avsnitt 5, sidorna 24-25.

En viktig, men ofta förbisedd, metod för att minska alla produktionseffekter är att förlänga användningen av befintliga produkter så mycket som möjligt. Detta sparar också pengar (se avsnitt 7, sidorna 30-31). Som upphandlare kan du hjälpa till genom att 1) välja en tålig fiber (se avsnitt 5, sidorna 24-25), 2) välja färger som klarar tvättning och användning av patienter och personal bra, 3) ställa upp kriterier för tvättservice som minskar slitaget på textilierna. Några miljömärkningar (se avsnitt 4) omfattar kriterier för slitstyrka, till exempel europeiska (EN) och nationella standarder för textilier ${ }^{2}$, men dessa är mycket grundläggande. Det är bättre att få dokumentation

\footnotetext{
${ }^{1}$ EEA (2014) Environmental Indicator Report 2014 http://www.eea.europa.eu/publications/environmental-indicator-report-2014

${ }^{2}$ Se exempelvis internationella och norska standarder katalogiserade av Norsk Standard på https://www.standard.no/no/Nettbutikk/produktkatalogen/?Prod Cat $=11360430$
} 


\section{SJUKHUSLOGOTYPER OCH ONÖDIGT SLÖSERI}

Det finns två situationer som kan leda till kassering av stora mängder i övrigt välfungerande hälso-och sjukvårdstextilier: 1) byte av det serviceföretag som ni hyr textilierna från och 2) ny/ändrad logotyp för sjukhuset, distriktet eller regionen.

Det finns flera olika alternativ för att undvika detta betydande resursslöseri:

1. Skriv in i avtalet med ett textiltjänsteföretag att textilierna får köpas tillbaka av sjukhuset i slutet av avtalsperioden.

2. Välj att ha neutral märkning av textilierna som kan användas av flera vårddistrikt, sjukhus och så vidare.

3. Fråga er leverantör om textilierna kan märkas med borttagbar logotyp.

från leverantörerna om hur många användningar/ tvättcykler som textilierna tål.

Effekter av användningsfasen: Hygien är naturligtvis den främsta prioriteringen vid tvätt av textilier. Det finns dock metoder för att minska effekterna av tvättningen utan att kompromissa med hygienen. Dessa inkluderar ökad vatten- och energieffektivitet, användning av miljövänligare tvättmedel och miljöeffektiv logistik. I vissa länder (som Danmark och Norge) tillåter sjukhusens riktlinjer för tvätthygien lägre tvättemperaturer, förutsatt att tvättmedel används som har samma steriliserande effekt (se sidorna 16-17).

Den nordiska Svanenmärkningen för textiltjänster ger en omfattande översikt över möjliga förbättringar. Observera dock att man för tvättservice med en nordisk Svanenmärkning kanske bara har vidtagit de allra viktigaste miljöförbättringarna (se avsnitt 4, sidan 22 för mer information om detta).
Slutligen kan, även om detta inte ingår i den nordiska Svanenmärkningen, valet av fiber påverka effekterna av tvättprocessen (se avsnitt 5 på sidan 24).

Vad som ska hända med uttjänta produkter är också ofta ett problem när man ska fatta miljövänliga beslut. Att säkerställa att en leverantör av textiltjänster återvinner sina textilier då de är uttjänta kan innebära vissa fördelar, men detta är inte lika viktigt för den totala miljöpåverkan som att förlänga användningsfasen.

En översikt över miljöeffekter finner du i Upphandlingsmyndighetens bakgrundsdokument för textilier och i myndighetens bakgrundsdokument för textiltjänster samt i en livscykelanalysrapport från EU-kommissionens gemensamma forskningscentrum. 


\title{
Avsnitt 2
}

\section{Upphandlingsprocessen, marknadsdialog och innovation}

\author{
En upphandlingsprocess kan vara komplex och involverar många steg och \\ strategiska beslut. Om miljökriterier ska inkluderas, bör detta beslutas i den \\ förberedande fasen för att säkerställa att rätt frågor ställs och beslut fattas vid \\ rätt tidpunkt.
}

Ett första beslut att beakta är om man ska upphandla produkter eller upphandla funktioner. När produktgruppen är textilier, innebär det att det kommer att vara relevant att överväga om man ska köpa textilier eller köpa tillgång till textilier - vilket innebär att man hyr dem.

Att hyra textilier kan få en potentiellt positiv effekt på miljöpåverkan. Det beror på att äganderätten till produkten kvarstår hos leverantören, som har ett ekonomiskt intresse av att säkerställa att produkten får en lång livslängd. Ju längre en produkt används, desto lägre blir miljöpåverkan och användningen av begränsande resurser.

Oavsett om man beslutar sig för att köpa eller hyra textilier och textiltjänster, är det viktigt att starta/börja med en marknadsdialog. Det är via marknadsdialogen som man kan få kunskap om vilka produkter som finns tillgängliga, om deras miljöegenskaper och om andra relevanta kvalitetsrelaterade aspekter (se exempel på sidan 11).

Marknadsdialog är en dialog mellan kunden och potentiella leverantörer som genomförs innan en formell upphandlingsprocess för att säkerställa att kraven $\mathrm{i}$ upphandlingsdokumentet är realistiska och återspeglar vad som finns tillgängligt på marknaden, men också är ambitiösa.
Det finns många metoder för att genomföra denna dialog, men vad som är viktigt att komma ihåg är att det är tillåtet fram till den tidpunkt då upphandlingsdokumentet offentliggörs. Efter offentliggörandet begränsa dialogen med potentiella leverantörer.

Vad bör du fråga i en marknadsdialog? Många aspekter kommer att vara relevanta att ta upp, men ur miljöperspektiv bör följande frågor diskuteras:

- Tillgången på miljömärkta produkter

- Tillgången på ekologiska bomullsbaserade produkter

- Användning av alternativa fibrer

- Textilfiberns ursprung

- Återvunnet innehåll

- Hantering av kemikalier, energi och vatten $\mathrm{i}$ produktionen

- Egenskaper relaterade till tvätt och underhåll

- Slitstyrka, inklusive möjligheten till reparation

- Borttagbara logotyper

- Färgval och miljökonsekvenser

- Potential för uttjänta textilier (kan de återvinnas?)

Mer inspiration för teman att diskutera med marknaden för att klargöra vilka miljökriterier som kan tillämpas hittar du i EU-kommissionens bakgrundsinformation om EU-GPP-kriterierna för textilier. 


\section{NORSKA SYKEHUSINNKJØP LÅTER MARKNADEN HJÄLPA TILL MED ATT STÄLLA UPP REALISTISKA KRITERIER}

Under 2014 upphandlade Sykehusinnkjøp HF (tidigare HINAS) textilier för sjuk- och hälsovårdssektorn och använde en marknadsdialogsprocess för att sätta samman lämpliga miljökrav. Leverantörer uppmuntrades att kommentera ett utkast till kriterier som sattes samman med genom dialogmöten. Leverantörerna bjöds in till dessa möten via en onlinedatabas för offentlig upphandling.

Effekterna av marknadsdialogen var att det blev en förskjutning i upphandlingskraven från $100 \%$ bomull till en mer tålig blandning av polyester och bomull. Leverantörerna rekommenderade att upphandlarna skulle efterfråga Öko-tex 100-märkta textilier som, även om de uppfyller mindre stränga krav, vid den tiden år 2014 kunde uppfyllas av betydligt fler leverantörer än miljömärkningar som den nordiska Svanen och EU Ecolabel.

Sykehusinnkjøp HF ger följande råd för marknadsdialog vid miljövänlig textilupphandling:

1. Ta vara på möjligheten att få marknadens kommentarer på era kriterier och hjälp med att säkerställa att de är realistiska - och även att de inte är oambitiösa.

2. Överväg enskilda dialogmöten för att säkerställa att leverantörerna kan tala fritt och inte hämmas av att konkurrenterna lyssnar.

3. Kom ihåg att låta leverantörerna utmana era upphandlingsvanor - inklusive ert val av fiber och affärsmodell.

Kontakta Evy Pleym på evy.pleym@sykehusinnkjop.no för mer information. 
Upphandlingsmyndigheten erbjuder stöd till statliga organisationer vid marknadsdialog. Stödet inkluderar möten och en workshop med myndigheten. Du hittar mer information här. Myndigheten håller också på att ta fram ett program för att utveckla onlineresurser för hjälp med marknadsdialogen. Resursbanken online omfattar ännu inte resurser för hälso- och sjukvårdstextilier.

På grund av den snabba utvecklingen av nya tekniker/metoder i produktionen av textilier, är det alltid viktigt att föra en marknadsdialog. Det kan finnas miljöförbättringar som upphandlare inom hälso- och sjukvårdssektorn inte känner till. Det finns många kommande innovationer inom produktionsprocesser och produktdesign som kan ge stora miljömässiga och hygieniska fördelar (se sidan 13).

Det bör noteras att innovativ teknik ibland kan riskera att införa nya miljöproblem och detta bör undersökas närmare innan man använder den.

Upphandlare kan också säkerställa att de senaste innovationerna används genom att underteckna ett utvecklingsavtal med leverantörer, det vill säga ett långsiktigt avtal med en leverantör som tillåter leverantören att använda nya tekniker när sådana lanseras för att minska miljöpåverkan ytterligare. Utvecklingsavtal kan potentiellt skapas kring funktionskriterier (se rutan nedan).

\section{ANVÄNDA FUNKTIONSKRITERIER I UPPHANDLINGSDOKUMENTEN}

I syfte att möjliggöra utveckling av nya produkter med lägre miljöpåverkan, kan ett upphandlingsavtal baseras på funktionskrav istället för att specificera en viss produkt. Detta används mest vid till exempel upphandling av energi- eller belysningstjänster men kan också användas för hälso- och sjukvårdstextilier. Ett krav kan till exempel vara leverans av rena sjuksköterskekläder för ett visst antal heltidsanställda sjuksköterskor som uppfyller minimikrav beträffande hygien, slitstarkhet och komfort istället för krav på en viss fibertyp. Fibrer kan sedan väljas av tjänsteleverantören som uppfyller dessa standarder men med största hållbarhet för att minska leverantörens kostnader och miljöpåverkan.

Upphandlingsmyndigheten har tagit fram en guide för att ställa upp funktionella kriterier som du hittar här. 


\section{EXEMPEL PÅ LOVANDE INNOVATIONER}

\section{Torrfärgning}

Ett antal innovativa företag har utvecklat torrfärgningsprocesser. Ett exempel använder $\mathrm{CO}_{2}$ istället för vatten och tillsätter inga extra kemikalier till processen för att lösa färgämnena. $\mathrm{CO}_{2}$ kan dessutom återvinnas och återanvändas. Med torrfärgning undviks utsläpp i form av avloppsvatten som kan stå för en stormiljöpåverkan hos produktionsföretag och även behovet av torkning av textilier mellan processer, vilket sparar energi.

\section{Biomimetik}

Biomimetik är tillämpningen av naturens designer på konstgjorda produkter. Forskning på det här området har redan lett till utvecklingen av textilier med egenskaper som liknar lotusbladets smutsavvisande egenskaper. Andra naturliga behandlingar har fokuserat på att efterlikna de antimikrobiella egenskaperna hos krabb- och hummerskal. Tillämpningen av dessa tekniker på textilier går redan framåt och kan leda till textilier som kan tvättas vid lägre temperaturer, samtidigt som en hög hygiennivå kan bibehållas.

\section{Nanomaterial}

Integration av nanomaterial i textilsubstrat kan öka textiliernas slitstyrka och därmed minska resursförbrukningen och -kostnaderna. Nanomaterial kan ge smutsavvisande egenskaper, motverka skrynklor, statiska laddningar och elektrisk ledningsförmåga för fibrerna utan att textiliens komfort och flexibilitet påverkas. 


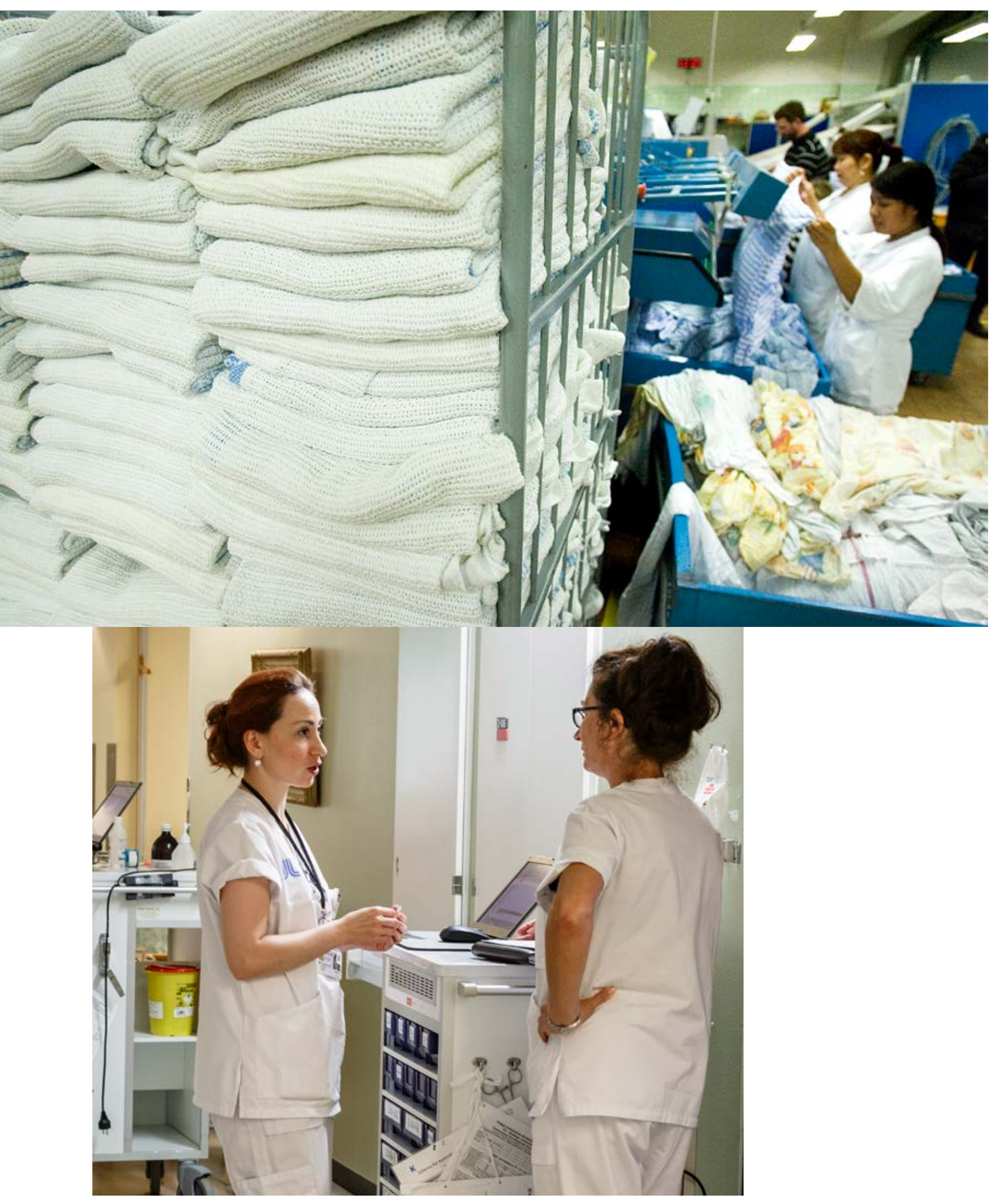




\title{
Länkar till användbara dokument och resurser
}

\author{
Det finns ett antal befintliga guider som kan hjälpa upphandlare ta hänsyn till \\ hållbarhet vid upphandling av textilier och textiltjänster. Ingen av dessa är specifikt \\ avsedd för textilier för hälso- och sjukvårdssektorn.
}

EU: EU tog fram miljökrav för upphandling av textilier under 2012. De är frivilliga

att använda och består av följande övergripande punkter:

Viktiga miljöeffekter

Strategi för miljöanpassad

offentlig upphandling

- Luftföroreningar, ozonbildning (smog), bioackumulering eller näringskedjeexponering och farliga effekter på vattenlevande organismer eller ökad tillväxt av oönskade vattenlevande organismer som kan försämra vattenkvaliteten till följd av olämplig användning av vissa bekämpningsmedel och gödningsmedel i produktionen av fibrer och ämnen som används under behandlingen av fibrerna och de slutliga textilprodukterna

- Negativ inverkan på hälsan för de användare som använder produkten i arbetet till följd av rester av vissa ämnen som är skadliga för människors hälsa

- Undvika tidig kassering och därmed slöseri med textilier genom att främja färgfasta tyger som inte krymper under tvätt
- Köp ekologiskt framställda textilier

- Köp begagnade textilier som kan återanvändas för sitt ursprungliga ändamål eller köp textilier som innehåller returfibrer

- Köp textilier som har framställts med minskad användning av miljöskadliga ämnen i produktionen

- Köp textilier med mindre rester av ämnen som är skadliga för människors hälsa

- Köp textilier som uppfyller minimikraven för färgbeständighet och dimensionsstabilitet
Kriterierna omfattar grundläggande (minimum) och mer omfattande (ambitiösare) kriterier för

- rester av bekämpningsmedel i naturfiberprodukter

- rester av kemikalier och ämnen som potentiellt används i tillverkningsprocesser

- restriktioner för användning av vissa färgämnen

- slittålighetsegenskaper som form- och färgbeständighet

Kriterierna inkluderar även förslag för tilldelning av poäng för ekologisk produktion av naturfibrer och andelen returfibrer i en produkt.

I EU-GPP-kriterierna gäller de flesta restriktionerna för farliga kemikalier förekomsten av rester i slutprodukten och inte för användning under produktionen. Undantaget är vissa färgämnen som EUGPP-kriterierna specifikt förbjuder i produktionen.
Restriktioner för rester av farliga kemikalier i slutprodukten leder dock sannolikt också till lägre användning under produktionen. EU-GPPkriterierna har även ett tilldelningskriterium för att gynna produkter i ekologisk bomull och andra ekologiska naturfibrer vilket minskar användningen av bekämpningsmedel.

GPP-kriterierna är i allmänhet mindre stränga än vanligt förekommande miljömärkningar som den nordiska Svanen och EU Ecolabel (se avsnitt 4, sidan 22). EU-GPP kriterierna är för närvarande under uppdatering och en reviderad uppsättning förväntas under 2017.

Nationellt: Nationella upphandlingsmyndigheter i vissa nordiska länder använder EU-kriterierna direkt som vägledning för upphandling av textilier, till exempel Danmark, Norge och Finland. 


\section{NATIONELLA STANDARDER FÖR HYGIEN I TVÄTTERIER FÖR TEXTILER FRÅN HÄLSO-OCH SJUKVÅRDEN}

Även när hållbarhetskriterier för upphandling av tvättservice används måste upphandlarna också följa nationella riktlinjer för minimiregler beträffande hygienstandarder för dessa tjänster.

EU-standarden EN 14065 beskriver en riskhanteringsmetod för att kontinuerligt kvalitetssäkra den mikrobiologiska kvaliteten på textilier behandlade i tvätterier och detta har översatts till motsvarande nationella standarder. Standarden EN 14065 har nyligen uppdaterats. Länkar till EU-standarden och de motsvarande nationella standarderna hittar du genom att klicka här: EU-standarder, dansk version, svensk version, finsk version, norsk version.

Standarden EN 14065 behandlar tröskelvärden, kontroller och övervakningssystem för biokontaminering i olika skeden av tvättcyklerna snarare än att definiera tvättmetoder för att undvika biokontaminering.

Minst tre nordiska länder har dock standarder eller riktlinjer som definierar tvätterioch tvättservicemetoder som ska följas för att undvika biokontaminering.

- Den danska standarden för hantering av textilier för hälso- och sjukvårdssektorn som används flera gånger

- Den svenska handboken för textilier i hälso- och sjukvården

- Den norska standarden för infektionskontroll för tvätterier som behandlar hälso- och sjukvårdstextilier 
Dessa skiljer sig åt beträffande krav på tvättemperatur under termisk desinfektion. Den norska standarden kräver 85 grader C i 10 minuter, den danska standarden minst 80 grader $\mathrm{C}$ i 10 minuter och den svenska handboken rekommenderar minst 70 grader $\mathrm{C}$ i 10 minuter.

Både den norska och den danska standarden tillåter lägre tvättemperaturer om tvättmedel används som har likvärdig steriliserande effekt. Likvärdigheten måste övervakas regelbundet. Enligt ett ledande tvättjänsteföretag förekommer det miljömärkta tvättmedel som kan uppfylla dessa alternativa krav. Detta kan ge nettomiljöfördelar jämfört med sterilisering i höga temperaturer.

Den svenska handboken fungerar mer som vägledning än en obligatorisk standard. En vetenskaplig studie vid Akademiska sjukhuset i Uppsala fann att en sänkning av temperaturen till 60 grader $C$ inte ökade risken för biokontaminering under förutsättning att det följdes av torktumling i en temperatur som överskred 110 grader $\mathrm{C}$. Detta minskar ändå den sammanlagda energiförbrukningen under hela tvättcykeln (Tano och Melhus, 2014)*.

*Tano E. och Melhus A. (2014) Level of decontamination after washing textiles at $60^{\circ} \mathrm{C}$ or $70^{\circ} \mathrm{C}$ followed by tumble drying. Infect Ecol Epidemiol. 2014 Nov 11;4:24314. 


\section{CSR OCH TEXTILUPPHANDLING}

CSR (Corporate Social Responsibility) avser affärsmetoder som omfattar initiativ som medför fördelar för samhället. Detta inkluderar, förutom det miljöarbete som behandlas i denna guide, etiska arbetsförhållanden, korruptionsbekämpning och mänskliga rättigheter. Dessa aspekter är relevanta vid upphandling av vårdtextilier och har i vissa nordiska länder varit i fokus under många år.

I Sverige har till exempel alla regioner en gemensam uppförandekod som leverantörer måste skriva under och intyga att de följer. Uppförandekoden är baserad på FN:s allmänna förklaring om mänskliga rättigheter, Internationella arbetsorganisationens åtta grundläggande konventioner, FN:s konvention om barnets rättigheter, FN:s konvention mot korruption och relevant arbets- och miljölagstiftning i produktionslandet. Du hittar uppförandekoden här.

De svenska regionerna har också en gemensam webbportal med riktlinjer och information om CSR, där textilier behandlas som ett av nio riskområden vid hälso- och sjukvårdsupphandling. Utsedda regioner ansvarar för efterlevnad och granskning i varje specifik produktgrupp och textilproduktion har, som exempel, under de senaste åren granskats i Indien och Pakistan. Du hittar riskbedömningen här: http://www.h ållbarupphandling.se/riskomraden/textilier

Den danska upphandlingsmyndigheten inkluderar ytterligare etiska och miljömässiga principer som till viss del består av Global Compact-principerna.

Den norska myndigheten tillhandahåller även etiska hänsynstaganden. Här lyfter de fram initiativ som syftar till att ta itu med dåliga arbetsförhållanden inom textiltillverkningen: Better Cotton Initiative, Clean Clothes Campaign, ACCORD och IPEC. Av dessa är Better Cotton Initiative och ACCORD de mest användbara för upphandlare eftersom det finns information om vilka märken/tillverkare som ingår i initiativen. Det finns dock (ännu) ingen garanti för att kläder tillverkade för dessa medlemmar lever upp till initiativens principer och mål.

EU Ecolabel, den nordiska Svanen och Bra Miljöval inkluderar kriterier som omfattar arbetsrättigheter på textiltillverkningsplatsen (se avsnitt 4, sidan 22).

Andra användbara länkar:

- World Wide Responsible Apparel

- CSR compass 
Upphandlingsmyndigheten har hållbarhetskriterier för textilier som inkluderar både kriterier och ett omfattande bakgrundsdokument som beskriver den miljöpåverkan som orsakas av textilkonsumtionen, de bestämmelser som är relevanta för kemikalieanvändning i textilproduktion och slutligen en lista över farliga kemikalier och ämnen som kan begränsas med hjälp av hållbarhetskriterierna.

Denna lista över kemikalier går betydligt längre än de som ingår i EU:s icke-bindande EU-GPP-kriterier och närmar sig de kemikalierelaterade kriterierna i textilmärkningarna EU Ecolabel och Svanen.

Till skillnad från andra myndigheter tillhandahåller Upphandlingsmyndigheten också ett bakgrundsdokument och vägledning för upphandling av tvättservice. Dessa omfattar en rad frågor kring användning och hantering av kemikalier och tvättmedel i tvättprocesser och energianvändning och vattenförbrukning samt utsläpp till luften från tvättservice.

EU- och nationellt föreslagna GPP-kriterier kan alla mer än väl uppfyllas av de textilier som är certifierade enligt den nordiska Svanen, EU Ecolabel och Bra Miljöval. De svenska kriterierna för tvättservicekan likaså uppfyllas genom textiltservice certifierade enligt den nordiska Svanenmärkningen (se avsnitt 4, sidorna 22-24).

Att inkludera etiska kriterier i upphandlingsprocessen är inte ett fokusområde för den här guiden men några exempel för att inkludera sådana visas dock ändå i rutan sidan 18 .

I slutändan måste upphandlare välja kriterier som passar deras behov och miljömässiga (och etiska) ambitioner. På sidorna 20-21 visas ett urval av grundläggande kriterier som Sykehusinnkjøp HF, den centrala upphandlarorganisationen i Norge, använde i en nyligen genomförd upphandling av vårdarbetskläder. Upphandlingsdokumentet innehåller också ytterligare kriterier för uttjänta textilier som innehåller farliga kemikalier och kriterier för produktförpackningar. Kriterierna är mindre omfattande än EU:s GPP-kriterier.

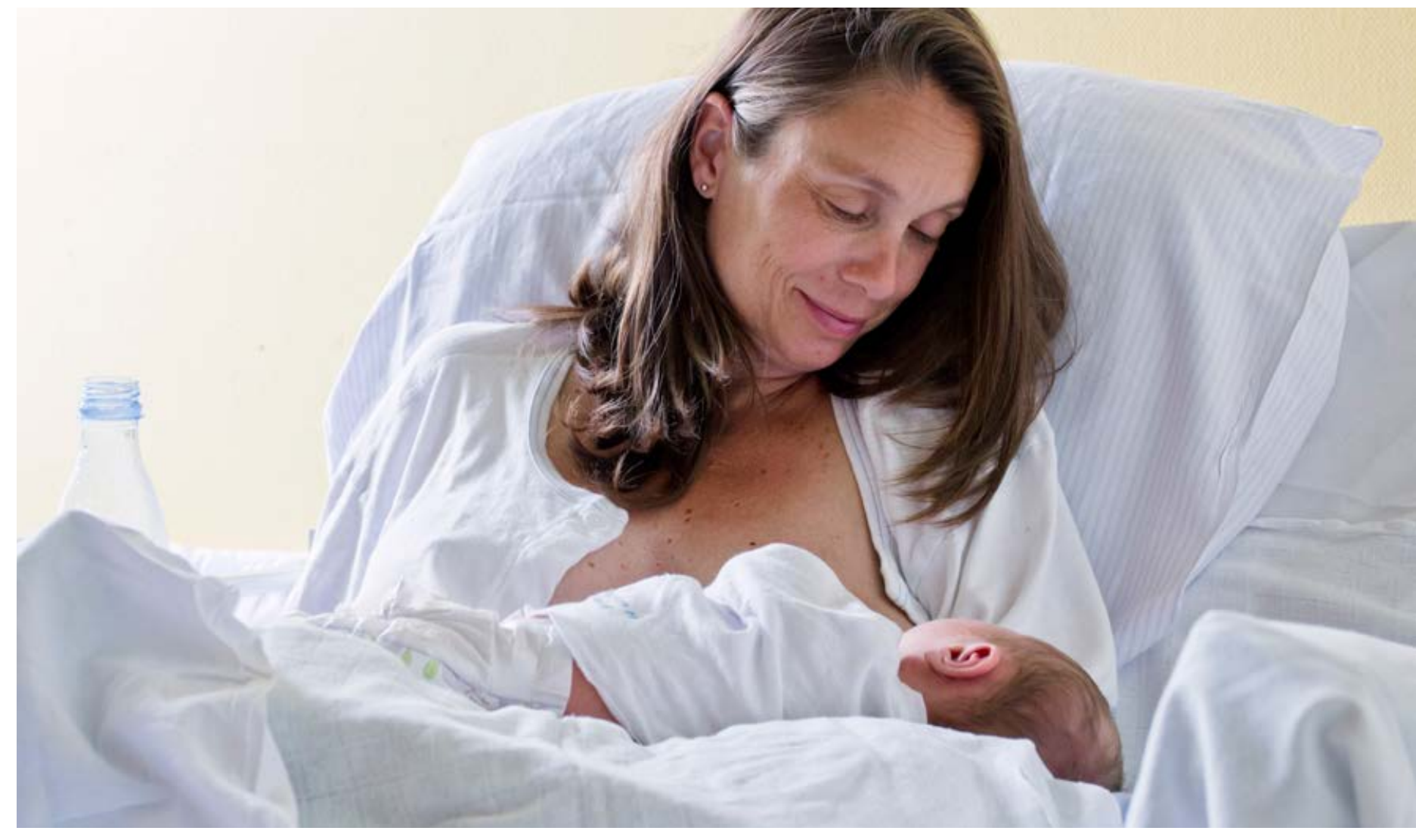




\section{Exempel på kriterier som använts i ett anbud för personalkläder}

\section{MINIMIKRITERIER FÖR KEMIKALIER}

\section{Efterlevnad av lagkrav}

De offererade produkterna måste uppfylla kraven i bestämmelserna om begränsning av användning av farliga kemikalier och andra produkter (produktbestämmelser (FOR-200406-01-922). De offererade produkterna måste överensstämma med kraven i kemikalielagstiftningen $\mathrm{REACH}$.

\section{Allmänna krav}

Produkterna får inte innehålla ämnen som förekommer på EU:s kandidatförteckning eller den norska prioriteringslistan. Detta gäller även användning av extra kemikalier och tvättmedel.

\section{Användning av bekämpningsmedel}

För produkter som tillverkas av bomull eller andra naturliga cellulosafibrer, bör slutprodukten inte innehålla mer än 0,05 ppm av vart och ett av följande ämnen och den totala halten bör inte överskrida 0,75 ppm:

-2,4,5-T, aldrin, kaptafol, klordan, klordimeform, DDT, dieldrin, dinoseb med salter, endrin, heptaklor, hexaklorbensen, hexaklorcyklohexan, $\alpha$, hexaklorcyklohexan, $\beta$, hexaklorcyklohexan, $\delta$, metamidofos, monokrotofos, paration, metylparation, propetamfos, toxafen

\section{Flamskyddsmedel}

Det bör inte finnas några kemiska flamskyddsmedel i de upphandlade plaggen, med undantag för då detta är absolut nödvändigt på grund av textiliernas funktion. Om flamskydd krävs ska detta anges i anbudsunderlaget. I sådana fall ska fosfor- och/ eller kvävebaserade organiska föreningar eller flamskyddsmedel med motsvarande eller bättre hälso- och miljöegenskaper eller flamhärdiga tyger användas. Halogenerade flamskyddsmedel får under inga några omständigheter användas.

\section{Alkylfenoletoxylater}

Produkten får inte innehålla alkylfenoletoxylater. (Nonylfenol begränsas av REACH, bilaga XVII och prioriteringslistan men kan ändå förekomma i produkter.) 


\section{LÄGSTA KVALITETSKRAV}

\section{Dimensionsförändringar under tvätt och torkning}

Dimensionsförändringarna efter tvätt och torkning får inte överstiga:

+/-3 \% för vävda produkter i bomull och bomullsblandning.

+/-2 \% för icke-vävda produkter i blandning av ull och syntetiska fibrer. $+/-4 \%$ för stickat.

$\pm 6 \%$ för grovstickat (tjockstickat).

$+/-5 \%$ för stickat (Interlock).

+/-7\% för frottéhanddukar och finribbstickat.

Kravet gäller inte för fibrer, garner, produkter som tydligt är märkta med "endast kemtvätt" eller motsvarande. Testerna ska vara utförda enligt EN ISO 6330, ISO 5077 eller motsvarande. Testerna ska göras enligt följande procedur Tvätta tre gånger med den temperatur som anges på produkten, med efterföljande torkning i torktumlare såvida inte någon annan torkprocedur anges på produkten.

\section{Färgbeständighet vid tvätt (tvättbeständighet)}

Tvättbeständigheten ska vara på minst nivå 3-4 för färgförändring och minst på nivå 3-4 för färgöverföring. Kravet gäller inte för produkter som tydligt är märkta "endast kemtvätt" eller motsvarande, för vita produkter eller produkter som varken är färgade eller har tryck. Testerna ska vara utförda enligt EN ISO 105-CO6 eller motsvarande. Detta innebär en enda tvätt vid temperaturen som anges på produkten.

\section{Beständighet mot våtnötning}

Beständigheten mot våtnötning ska vara minst på nivå 2-3. Kravet gäller inte vita produkter eller produkter som varken är färgade eller försedda med tryck. Testet ska vara utfört enligt ISO $105 \times 12$ eller motsvarande.

\section{Beständighet mot torrnötning}

Färgbeständigheten mot torrnötning ska vara minst på nivå 4. Kravet gäller inte vita produkter eller produkter som varken är färgade eller försedda med tryck. Testet ska vara utfört enligt EN ISO 105 X12 eller motsvarande.

\section{TILLDELNINGSKRITERIER}

\section{Ekologisk bomull eller andra naturfibrer} Poäng tilldelas enligt viktandelen bomulls- eller andra naturfiberprodukter som är ekologiskt odlade. För att betraktas som ekologiska måste fibrerna vara odlade i enlighet med Rådets förordning (EG) 834/2007 av den 28 juni 2007 om ekologisk produktion och märkning av ekologiska produkter och om upphävande av förordning (EEG) nr 2092/91. 
Avsnitt 4

\title{
En kort genomgång av miljömärkningarna
}

\author{
Beslut om att inkludera en miljömärkning $i$ ett upphandlingsdokument kräver \\ noggrann eftertanke och kunskap om vad varje miljömärkning innebär. Du bör välja \\ en miljömärkning som överensstämmer med dina miljömässiga ambitioner, men vara \\ försiktig så att du inte i för hög grad begränsar urvalet av potentiella leverantörer. \\ Det kan också vara så att ingen av miljömärkningarna täcker alla relevanta \\ miljöhänsyn, så att ytterligare miljökriterier behöver läggas till.
}

Sedan 2014 är det juridiskt möjligt inom EU

att specificera miljömärkningar direkt $i$ ett

upphandlingsdokument som kriterium, men bara

miljömärkningar som uppfyller vissa rapporterings-

och kvalitetssäkringskrav (se avsnitt 3.5.1 i handboken

Att köpa grönt!). Denna nya regel gör det enklare för upphandlare att ställa miljökrav och för leverantörer att verifiera att de uppfyller dem. I Danmark måste dock upphandlare tillåta leverantörer vars produkter skulle kunna uppfylla kriterierna men som inte har erhållit någon miljömärkning. Leverantörerna ska tillhandahålla dokumentation för detta och det innebär ett visst extraarbete för upphandlaren.

Det finns många märkningar för textilprodukter men bara den nordiska Svanen har tagit fram kriterier för textiltjänster. Relevanta miljömärkningar för vårdtextilprodukter inkluderar den nordiska Svanen, EU Ecolabel (kallas ibland för EU-blomman), GOTS (Global Organic Textile Standard) och Bra Miljöval.

Även om Oeko-Tex 100-märkningen inte är en strikt miljömärkning, används även den ibland som ett miljökriterium vid upphandling. BlueSign-märkningen används egentligen fortfarande bara för textilier för utomhusbruk och är därför ännu inte relevant för sjukhusupphandlare, möjligen med undantag för arbetskläder avsedda för utomhusbruk.

Observera att inte alla miljömärkningar överensstämmer med de kriterier som EUkommissionen fastställt i handboken Att köpa grönt! som medför att de får användas i upphandlingsanbud.
I tabellen nedan görs en kortfattad jämförelse av de miljöfrågor som tas upp i de mest relevanta märkningarna. Två bockar indikerar strängare och/ eller mer omfattande kriterier än en.

En jämförelse av samma märkningar avseende begränsningar av specifika kemikalier och ämnen har också tagits fram av Upphandlingsmyndigheten och den hittar du här.

Syftet med Oeko-Tex-märkningen är att skydda textilanvändare från farliga kemikalierester i kläder och textilier för försäljning. Begränsningar av kemikalier enligt övriga miljömärkningar gäller hela livscykeln och syftar till att minska effekterna på ekosystem och människor längs hela värdekedjan, inklusive slutanvändaren. Oeko-Tex har lanserat en märkning (STeP) som täcker miljöaspekterna av produktion men det rör sig om en märkning för miljöhantering på produktionsanläggningar, snarare än en produktmärkning. Den har därför begränsad relevans för upphandlare.

Den nordiska Svanen har också en märkning och kriterier för textiltjänster. Märkningen innehåller särskilda kriterier för tvätt av sjukhustextilier för att ta hänsyn till hygienstandarder. Kriterierna tar upp energianvändning, vattenförbrukning, användning av tvättmedel/kemikalier på tvätterier, förpackningar och transportlogistik. Märkningen innehåller också krav på en minsta andel miljömärkta textilier i textilier som hyrs ut via textiltjänster. 


\section{Kortfattad jämförelse mellan märkningar av textilprodukter}

\begin{tabular}{|c|c|c|c|c|c|}
\hline & $\begin{array}{l}\text { Nordiska } \\
\text { Svanen }\end{array}$ & $\begin{array}{l}\text { EU } \\
\text { Ecolabel }\end{array}$ & Bra Miljöval & $\begin{array}{l}\text { GOTS (endast } \\
\text { naturfibrer) }\end{array}$ & $\begin{array}{l}\text { Oeko-tex } \\
100\end{array}$ \\
\hline $\begin{array}{l}\text { Andel ekologiskt innehåll } \\
\text { (naturfiber) }\end{array}$ & $\checkmark$ & $\checkmark$ & $\checkmark \checkmark$ & $\checkmark \checkmark$ & \\
\hline $\begin{array}{l}\text { Innehåll av återvunnet } \\
\text { material }\end{array}$ & $\checkmark$ & $\checkmark$ & $\checkmark$ & & \\
\hline $\begin{array}{l}\text { Krav på kemikalier i } \\
\text { tillverkningsprocessen- } \\
\text { tionsprocess }\end{array}$ & $\checkmark \checkmark$ & $\checkmark \checkmark$ & $\checkmark \checkmark$ & $\checkmark \checkmark$ & \\
\hline $\begin{array}{l}\text { Begränsningar av rest- } \\
\text { kemikalier i produkten }\end{array}$ & $\checkmark \checkmark$ & $\checkmark \checkmark$ & & $\checkmark \checkmark$ & $\checkmark \checkmark$ \\
\hline $\begin{array}{l}\text { Hantering av vattenut- } \\
\text { släpp }\end{array}$ & $\checkmark \checkmark$ & $\checkmark \checkmark$ & $\checkmark \checkmark$ & $\checkmark \checkmark$ & \\
\hline $\begin{array}{l}\text { Minskade luftföroren- } \\
\text { ingar }\end{array}$ & & $\checkmark$ & $\checkmark \checkmark$ & & \\
\hline Minskat fast avfall & & & $\checkmark$ & $\checkmark$ & \\
\hline $\begin{array}{l}\text { Produktkvalitet och } \\
\text { hållbarhet }\end{array}$ & $\checkmark$ & $\checkmark$ & & $\checkmark$ & \\
\hline Förpackningsmaterial & $\checkmark$ & & $\checkmark \checkmark$ & $\checkmark \checkmark$ & \\
\hline $\begin{array}{l}\text { Arbetsrätt och arbets- } \\
\text { villkor }\end{array}$ & $\checkmark \checkmark$ & $\checkmark \checkmark$ & $\checkmark \checkmark$ & & \\
\hline $\begin{array}{l}\text { Certifiering } \checkmark \checkmark \text { Tredje } \\
\text { part } \checkmark \text { Andra part }\end{array}$ & $\checkmark \checkmark$ & $\checkmark \checkmark$ & $\checkmark \checkmark$ & $\checkmark \checkmark$ & $\checkmark \checkmark$ \\
\hline
\end{tabular}

Källa: Jämförelse utförd av Planmiljø

Som upphandlare kanske du vill ställa ytterligare kriterier. Dessa kan också inspireras av kriterierna i miljömärkningarna. En textiltjänsteleverantör kan till exempel få en nordisk Svanencertifiering om hen uppfyller minimikriterierna och dessutom får 15 poäng av 65 möjliga av de valfria kriterierna. En ambitiösare upphandlare kan välja att sätta ett högre tröskelvärde på till exempel 25 poäng för de valfria kriterier som tjänsteleverantörerna måste uppfylla.

Slutligen, innan du använder miljömärkningar i ett anbudsförfarande för en viss produkt, tänk på att se till att det finns minst två till tre leverantörer som kan uppfylla kriterierna. Annars kan det sluta med att du får betala ett icke-konkurrenskraftigt pris. De flesta miljömärkningar har en lista över produkter som har certifierats inom olika kategorier. Enmarkandsdialog är också till hjälp. (se avsnitt 2, sidorna 10-12).

Du hittar kriterierna för de olika miljömärkena här:

- Nordic Swan textiles.

- Nordic Swan textiles services.

- EU Ecolabel textiles.

- Bra Miljöval.

- GOTS.

- Oeko-tex 100. 
Avsnitt 5

\section{Välja fiber}

Att välja rätt fiber kan ge stora miljöfördelar ur många olika perspektiv. Exempelvis kan fibervalet påverka energiförbrukningen vid tvätt, produktens hållbarhet och produktionens miljöpåverkan. Fibern är också viktig ur komfort- och hygiensynvinkel.

När du väljer fiber för dina textilier är det viktigt att överväga egenskaperna och den därmed relaterade miljöpåverkan. Exempel:

\section{- Olika fibrer har olika miljöprofiler under} produktionen: Diagrammet längre ned har tagits fram hjälp av livscykelanalysmetoder. Bomull och polyester tenderar att ha större produktionspåverkan än vissa nyare fibrer. Toxicitetseffekterna ingår inte i diagrammet och dessa skulle placera bomull i något sämre läge på grund av den höga användningen av bekämpningsmedel vid konventionell bomullsodling. Effekterna kan minskas genom att använda ekologisk bomull.

- Vissa fibrer är mer hållbara än andra: Polyester eller en blandning av polyester och bomull kan klara/tåla fler tvättcykler än $100 \%$ bomull3. Man kan också öka livslängden genom att lägga till en finish som förenklar vården av textilierna.

- Syntetiska fibrer är lättare att tvätta: Eftersom de absorberar mindre vatten går det åt mycket mindre energi vid torktumling. Nya studier visar också att textiler av syntesfibrer kan tvättas vid lägre temperaturer än bomull utan att påverka hygienen, men detta återspeglas inte i gällande nationella hygienstandarder.

- Rena fibrer och syntetiska material är lättare att återvinna efter användning: $100 \%$ polyester kan i teorin återvinnas till nya textiler om och om igen. $100 \%$ bomull kan också återvinnas för användning i nya textilier, men måste blandas med $80 \%$ ny bomull för att upprätthålla textilkvaliteten. Det är svårare att återvinna fiberblandningar som polyester/bomull. Viktigt: Återvinning av sjukhustextilier får inte påverka textilens hållbarhet. En längre livstid för textilen ger mycket större miljöfördelar än återvinning.

- Syntetiska fibrer kan leda till marina mikroplastiska föroreningar även om detta är en mycket mindre källa än till exempel bildäck. Det förväntas att denna fråga kan hanteras $i$ framtiden genom utveckling av speciella avloppsvattenfilter på tvätterierna ${ }^{4}$.

\footnotetext{
${ }^{3}$ http://www.howstuffcompares.com/doc/c/cotton-vs-polyester.htm

${ }^{4}$ http://www.plasticsouplab.org/showcases/washing-machine-filter/
} 
Jämförelse av livscykelpåverkan från olika fibrer

\begin{tabular}{|c|c|c|c|c|c|}
\hline & Energy use & Water use & $\begin{array}{l}\text { Greenhouse } \\
\text { gasses }\end{array}$ & Waste water & $\begin{array}{l}\text { Direct land } \\
\text { use }\end{array}$ \\
\hline $\begin{array}{l}\text { Decreasing } \\
\text { environment al } \\
\text { impact }\end{array}$ & $\begin{array}{l}\text { Acrylic } \\
\text { Nylon } \\
\text { Polyester/ } \\
\text { PTT } \\
\text { Regen. } \\
\text { cellulosic } \\
\text { (viscose, } \\
\text { Modal) } \\
\text { PLA/ } \\
\text { Cotton/ } \\
\text { Lyocell } \\
\text { Wool } \\
\text { Natural } \\
\text { bast fibres } \\
\text { (nettle, } \\
\text { hemp, flax) }\end{array}$ & $\begin{array}{l}\text { Cotton } \\
\text { Silk } \\
\text { Nylon } \\
\text { Regen. } \\
\text { cellulosic } \\
\text { Acryl } \\
\text { Hemp } \\
\text { Wool } \\
\text { Natural bast } \\
\text { fibres } \\
\text { Polyester }\end{array}$ & $\begin{array}{l}\text { Nylon } \\
\text { Polyester } \\
\text { Lyocell } \\
\text { PLA } \\
\text { Viscose } \\
\text { Modal } \\
\text { Cotton } \\
\text { Natural bast } \\
\text { fibres } \\
\text { Wool }\end{array}$ & $\begin{array}{l}\text { Wool } \\
\text { Regen. } \\
\text { cellulosic } \\
\text { Natural bast } \\
\text { fibres } \\
\text { Nylon } \\
\text { Polyester }\end{array}$ & $\begin{array}{l}\text { Wool } \\
\text { Ramie } \\
\text { Cotton } \\
\text { Flax } \\
\text { Hemp } \\
\text { Viscose } \\
\text { and Modal } \\
\text { Jute } \\
\text { PLA } \\
\text { Lyocell }\end{array}$ \\
\hline
\end{tabular}

Källa: EU:s tekniska bakgrundsrapport till GPP-kriterierna för textilier 2011

Den fiber som används måste också uppfylla andra krav, inte minst hygienstandarder (till exempel infektionskontroll för operationssalstextilier, se avsnitt 6, sidorna 28-29) och krav på användarkomfort.

\section{Komfort: Är bomull verkligen bäst?}

Trots sina miljömässiga nackdelar kan bomull vara den föredragna fibern när det gäller komfort för sjukhuspersonal och patienter. Detta kan dock baseras på förutfattade meningar, snarare än faktisk erfarenhet.

Laboratorietester av komfort har utförts med hjälp av standardiserade testtekniker för att mäta:
- Värmeledningsförmåga

- Resistens för vattenånga

- Luftgenomsläpplighet

- Ytfriktion och grovhet (Kawabata Evaluation System)

- Fukthantering (AATCC-standarden)

- Draghållfasthet

Men för att möta förutfattade meningar kan det vara en bra idé att låta personal och patienter testa olika textilalternativ innan ett slutgiltigt beslut fattas. Användartester kan visa att alternativa fibrer ger mer än acceptabel komfort för personalen, samtidigt som de ger miljömässiga och ekonomiska fördelar ${ }^{5}$. Se rutan på sidan 26 för ett exempel på ett pilotprojekt som visade just det.

${ }^{5}$ http://www.greenercleaner.net/natural-or-synthetic-textiles/ 


\section{INNOVATIV UPPHANDLING AV PERSONALKLÄDER PÅ SJUKHUSET I RAWICZ}

År 2011 deltog länssjukhuset i Rawicz i Polen i LCB-Healthcare Network, ett EUfinansierat nätverk för innovativ upphandling. Ett pilotprojekt för innovativ upphandling lanserades på sjukhuset med inriktning på hållbar upphandling av personalkläder.

Pilotprojektet inleddes med att ställa frågor till sjuksköterskor, läkare och annan personal om de viktigaste funktionsparametrarna för personalkläder. Personalen uppskattade att bli tillfrågade och hade följande åsikter: de nya personalkläderna måste vara funktionella, snygga, användarvänliga, lätta att tvätta, hållbara och kostnadseffektiva.

Genom att specificera dessa funktionsresultat i upphandlingsdokument, istället för att specificera material, fibertyp, design och så vidare, fick inköpare och leverantörer möjligheten att undersöka mer innovativa lösningar. Efter att ha väckt intresse för pilotprojekts resultaten hos ytterligare åtta sjukhus i Polen, blev det dessutom möjligt att få ett brett utbud av leverantörer att lämna anbud.

Sjukhuset kommunicerade proaktivt sina behov och marknadskrav och ett öppet möte hölls med potentiella leverantörer. Återkopplingen var mycket positiv och den öppna specifikationen gav leverantörerna möjlighet att särskilja sina produkter med andra faktorer än inköpspris. I synnerhet den totala ägandekostnaden (TCO - se avsnitt 7, sidorna 30-31) gavs företräde framför inköpskostnaden när man utvärderade erbjudandena från leverantörerna.

Resultatet av marknadsdialogen och anbudsförfarandet blev personalkläder tillverkade av en blandning av polyester och Tencel (en eukalyptusbaserad produkt). Materialblandningen fanns vara lika tålig under tvättprocessen, torkade snabbare, var mindre fläckbenägen än ren bomull och klarade kraven beträffande kvalitet och funktion. Även om inköpspriset var högre än i vissa konkurrerande bud, hade materialblandningen den lägsta totala ägandekostnaden, på grund av minskade tvättkostnader och längre livslängd.

Vänligen kontakta Marcin Kautsch via e-post för mer information: mxkautsc@wp.pl 


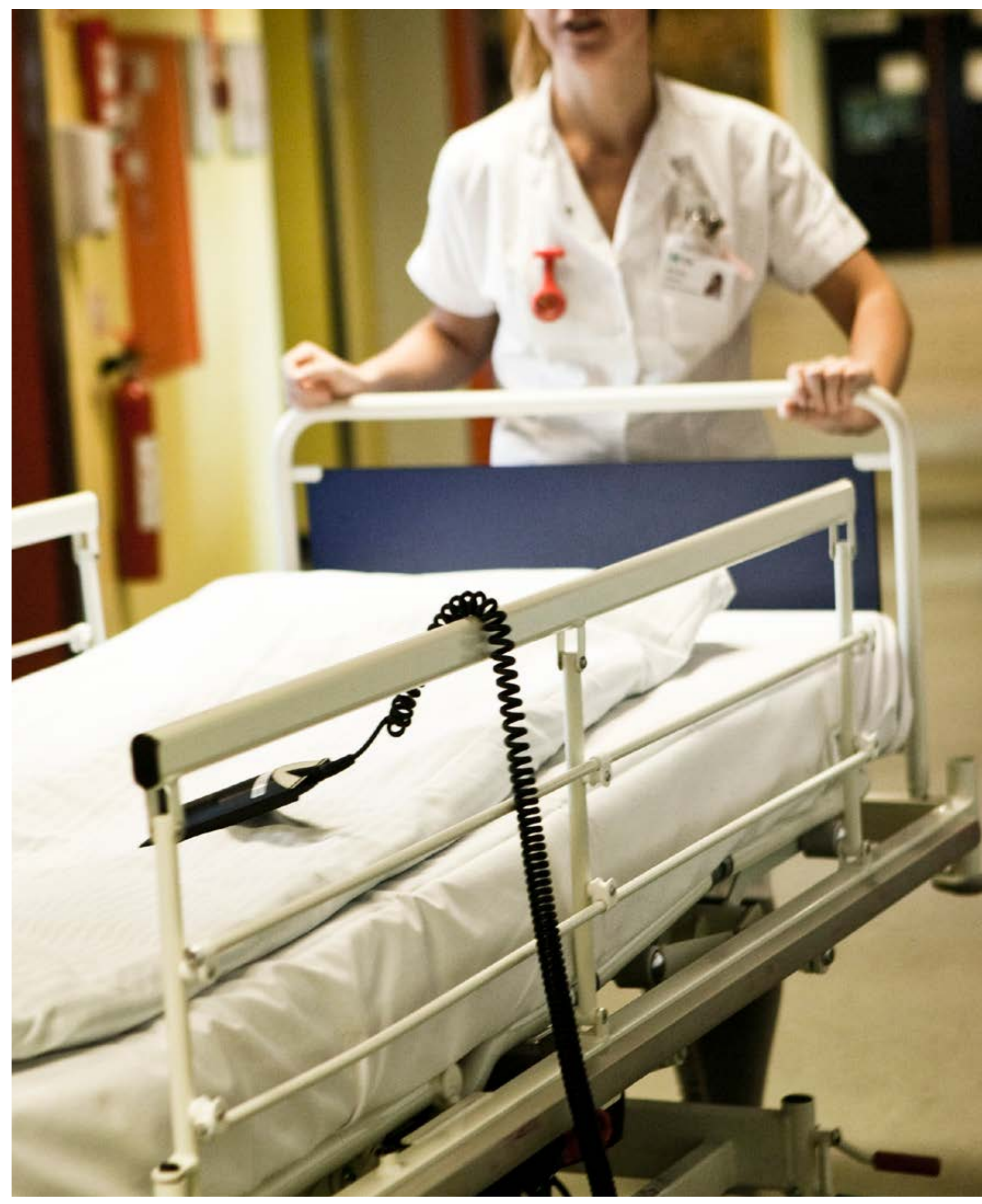


Avsnitt 6

\section{Engångstextilier jämfört med flergångstextilier}

Det finns för- och nackdelar med både engångsprodukter och textilprodukter för flergångsanvändning Detta är särskilt fallet för operationssalstextilier där infektionskontroll är av största vikt. Utöver hygien är andra viktiga variabler total kostnad per användning, funktion och komfort och, vad som är mest relevant här, miljöhänsyn.

Engångstextilier och moderna flergångs-operationstextilier är mer eller mindre jämförbara avseende barriärskydd, vilket är en avgörande faktor för infektionskontroll. Detta är beroende av att flergångstextilier tvättas och steriliseras enligt godkända förfaranden efter varje användning.

Att minimera frisättningen av luftburna partiklar är också av betydelse för infektionskontroll. Moderna flergångsbarriärtyger framställda av kontinuerliga trådar/fibrer har mycket lägre potential för att släppa ludd än traditionella bomullstyger och fungerar lika bra som icke-vävda engångstextilier. De ger också god komfort och andningsförmåga.

Studieresultaten varierar vad gäller kostnaden per användning för engångsprodukter jämfört med återanvändbara produkter och resultaten är i högsta grad landsspecifika. Högre arbetskraftskostnader kan gynna engångstextilier, medan höga kostnader för avfallshantering gynnar flergångstextilier.
Å andra sidan finner flera studier att flergångstextilier ger betydande miljöfördelar jämfört med textilier för engångsbruk $k^{6,7,8,9}$. En genomgång av sex livscykelanalyser visade att engångstextilier ger två till tre gånger större koldioxidavtryck, energianvändning och vattenförbrukning per användning i operationssalen än moderna flergångstextilier ${ }^{10}$. Eftersom moderna flergångstextilier är bättre eller jämförbara med engångsprodukter i andra avseenden, verkar de vara det mer hållbara valet.

\section{Jämförelse av operationstextilier - flergångstextilier och engångstextilier}

Användning av flergångsoperationstextilier är beroende av att sjukhuset har kapacitet att sterilisera återanvändbar operationsutrustning.

Följande råd kan ges till sjukhus och deras tvättservice som vill gå över från operationstextilier för engångsbruk till flergångstextilier ${ }^{11}$ :

\footnotetext{
${ }^{6}$ Overcash (2012) A Comparison of Reusable and Disposable Perioperative Textiles: Sustainability State-of-the-Art 2012 http://www.ncbi.nlm.nih.gov/pubmed/22492184

${ }^{7}$ Carre (2008) LCA Comparing Laundered Surgical Gowns with Polypropylene Based Disposable Gowns http://trlaa.com.au/wordpress/wp-content/uploads/Lifecycle_Assessment_Study.pdf

${ }^{8}$ Mikusinska (2012) Comparative Life Cycle Assessment of Surgical Scrub Suits

http://kth.diva-portal.org/smash/get/diva2:574013/FULLTEXTO1.pdf

${ }^{9}$ Eriksson och Berg (2003) Livscykelanalys av Operationsrockar

http://www.vgregion.se/upload/Tv\%C3\%A4tteriet\%2OAlings\%C3\%A5s/LCA\%2Ooperationsrockar_granskad.pdf

${ }^{10}$ Overcash (2012) A Comparison of Reusable and Disposable Perioperative Textiles: Sustainability State-of-the-Art 2012 http://www.ncbi.nlm.nih.gov/pubmed/22492184

${ }^{11}$ https://americanlaundrynews.com/articles/winning-sale-reusable-surgical-textiles-part-1
} 


\begin{tabular}{|l|c|c|c|}
\hline & Cotton reusable & Disposables & High tech reusable \\
\hline Barrier effect & - & + & + \\
\hline Cleanliness & + & $?$ & + \\
\hline Particle emission & - & - & + \\
\hline $\begin{array}{l}\text { Comfort and } \\
\text { breathability }\end{array}$ & + & - & + \\
\hline Environmental impact & $+/-$ & + & + \\
\hline Functionality & - & + - & $+/-$ \\
\hline Cost effective & $+/-$ & $+/-$ & + \\
\hline Value for money & - & & + \\
\hline
\end{tabular}

Källa: Petel, M. (2014) ${ }^{12}$

1. Börja i liten skala. Börja med en hanterbar plan, till exempel operationshanddukar och operationsrockar.

2. Arbeta med din leverantör av flergångsoperationstextilier. Ta del av den kunskap och de resurser som leverantören kan tillhandahålla. Kontakta andra tvätterier som framgångsrikt har hjälpt sjukhus med program för flergångsoperations-

3. textilier.

4. Ta fram en översikt som jämför engångsprodukter med återanvändbara alternativ. Denna jämförelse bör innehålla kostnader, produkt- och barriäregenskaper, sterilisering, kasseringskostnader, leverans, bemanning och alla andra tjänster som tvätteriet kan erbjuda.
5. När din plan godkänts, sätt samman ett multidisciplinärt team.

6. Ge teamet (miljöansvariga, klinisk personal och beslutsfattare) en rundtur i tvätt- och utrustningsrummet.

7. Pröva att testa en textil under ett par veckor. Det kan finnas motståndare till flergångsprodukter, men låt dem prova det.

8. Skapa en tydlig process för att genomföra den faktiska övergången (en som innebär att man använder upp redan befintliga engångsprodukter och så vidare).

9. Fortsätt med stöd och utbildning till personalen och utvärdera och mät resultaten. 


\title{
Tillämpa den totala ägandekostnaden som parameter
}

\author{
Den totala ägandekostnaden är kostnaderna för en produkt under hela dess \\ livslängd, från inköp till kassering. Att fatta beslut baserat på total ägandekostnad, \\ snarare än inköpspris, kan ge miljömässiga fördelar.
}

När man väljer mellan textilprodukter är oftast inte den billigaste produkten den mest miljövänliga. Men när livscykelkostnaderna för en produkt räknas in, kan det finnas en större kompatibilitet mellan miljövinster och budgethantering. Detta är särskilt fallet för mer hållbara textilier, vilket sparar både pengar och miljöresurser, även om de kan kosta mer vid själva inköpet. Valet mellan textilier för engångsbruk och flergångstextilier (se avsnitt 6, sidorna 28-29) kan också bli tydligare efter beräkning av livscykelkostnaderna eller den totala ägandekostnaden, som det också kallas.

Den totala ägandekostnaden är kostnaderna för en produkt under hela dess livslängd, från inköp till kassering. Den ger ett ramverk och ett språk för att beskriva och mäta hållbarhetseffekter på ett sätt som upphandlingschefer lätt kan förstå. Den totala ägandekostnaden kan till exempel användas tillsammans med livscykelanalys (LCA) och liknande metoder för att upptäcka (och förmedla) möjligheter till både kostnadsbesparingar och hållbarhetsfördelar för delar som energi- och vatteneffektivitet.

Att ta hänsyn till den totala ägandekostnaden kräver kunskap om de faktorer som måste ingå i beräkningarna och en bra överblick över hur produkten används. För hälso- och sjukvårdstextilprodukter omfattar detta kunskaper om:
- inköpspris

- antal användningar innan produkten slits ut

- energianvändning och vattenförbrukning vid tvätt och associerade kostnader

- behov av och kostnader för reparation

- kostnader för kassering

Du kan använda den totala ägandekostnaden för att välja mellan olika textilleverantörer (se fallet med sjukhuset i Rawicz på sidan 28). Kom ihåg att få leverantörerna att dokumentera hållbarheten (antal användningar före kassering) för deras textilier, eftersom detta är nyckelfaktorn för den totala ägandekostnaden. Inkludera om möjligt en avtalsklausul som stipulerar denna nivå.

De flesta större textilföretag har tagit fram totala ägandekostnader för att minimera sina kostnader och kan göra dessa beräkningar åt dig. Detsamma kan gälla för nationella inköpare som Sykehusinnkjøp HF i Norge. Upphandlare på regional, kommunal eller sjukhusnivå kan dock tycka att det är för resursintensivt att ta fram beräkningar av totala ägandekostnader för alla produkter som de köper, inklusive textilier.

Även om det finns ett antal verktyg och tips att dra nytta av vid beräkning av totala ägandekostnader, finns det ännu inte några offentligt tillgängliga beräkningsmetoder för hälso- och sjukvårdstextilprodukters totala ägandekostnad. Du hittar mer generaliserad information och verktyg här: 


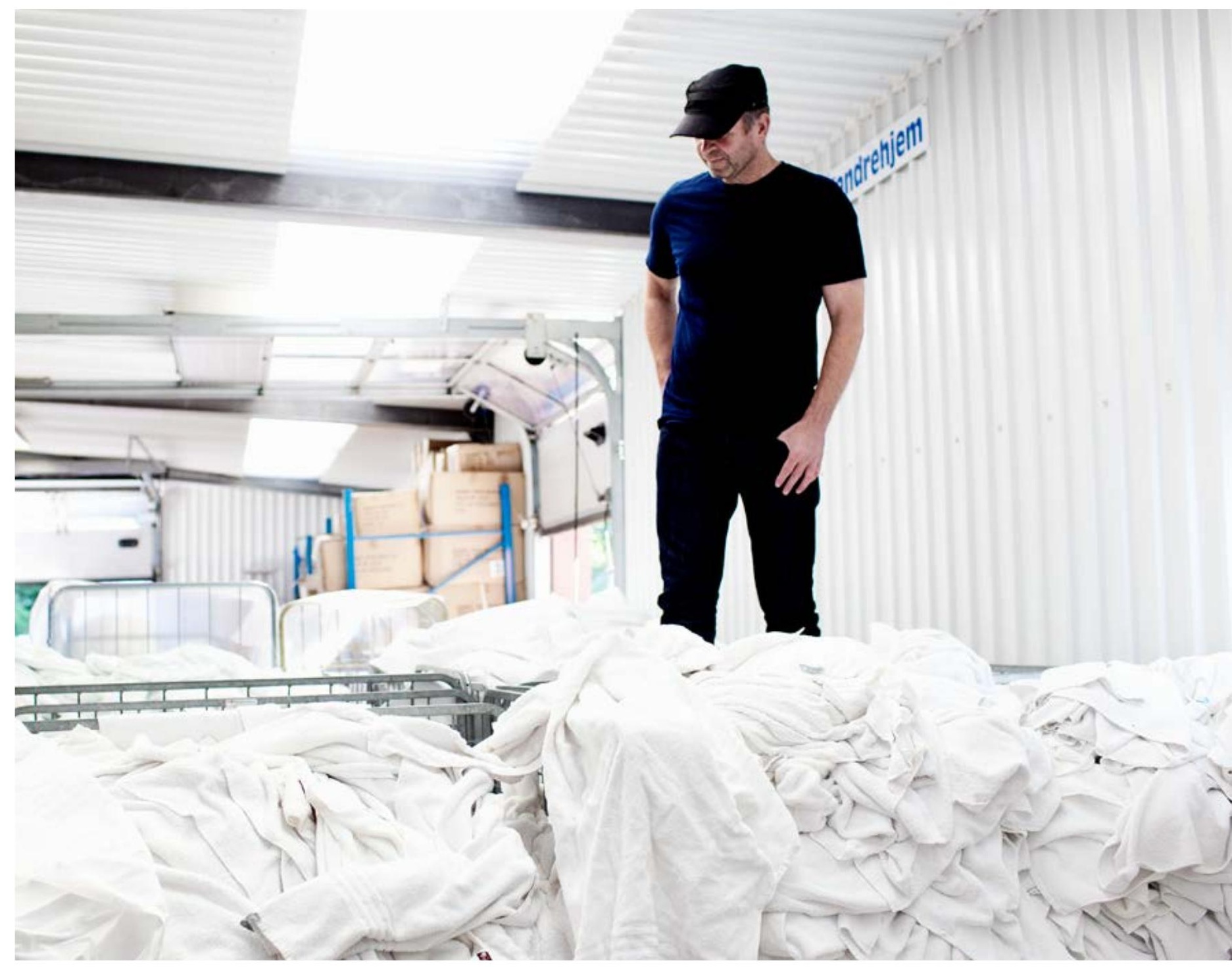

- Det danska forumet för hållbar upphandling - ett nationellt nätverk som är ett forum för kunskapsdelning där inköpare från både offentliga och privata organisationer kan hålla sig uppdaterade om bästa praxis, metoder och verktyg för miljövänlig upphandling, inklusive verktyg för den totala ägandekostnaden (danska)
- Den ansvarsfulla inköparen - en webbsida där upphandlare kan hitta miljövänliga kriterier redo att kopieras och klistras in i anbudsdokument för ett antal produktområden samt verktyg för den totala ägarkostnaden för utvalda produktområden (danska)

- BSR (Business for Social Responsibility) (engelska) 


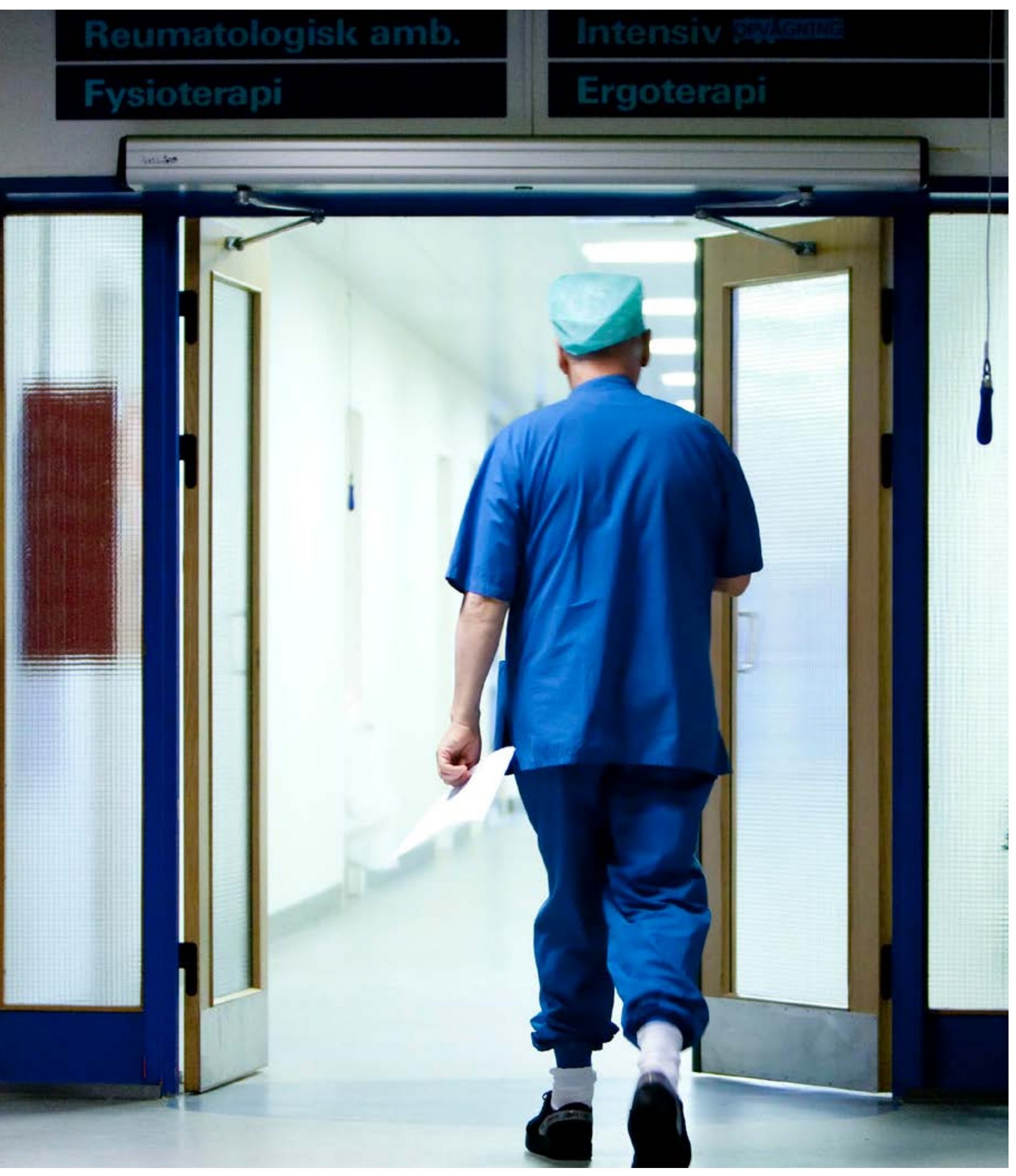


Avsnitt 8

\section{Om guiden och nätverket bakom}

Den här guiden har utvecklats som ett led $i$ ett initiativ inom den nordiska

handlingsplanen för hållbart mode och textilier, "Norden - välklädd i en ren miljö" och

finansieras av Nordiska ministerrådet.

Den nordiska handlingsplanen identifierar hållbar offentlig upphandling som en viktig hävstångseffekt. För det första eftersom den offentliga sektorn i sig är en betydande konsument av textilier - med ett värde på 10 miljarder euro per år på EU-nivå ${ }^{13}$. För det andra för att hållbaroffentlig upphandling kan etablera marknader som kan få positiva spridningseffekter och inspirera privata upphandlare att följa efter.

Guiden har utvecklats i samarbete med ett nordiskt nätverk av upphandlare inom hälso- och sjukvårdssektorn. Nätverket har initierats av den danska Miljöstyrelsen på Nordiska ministerrådets vägnar. PlanMiljø ApS och TEM har hjälpt till i processen, möjliggjort nätverket och utarbetat guiden. Nätverket består av följande medlemmar:

Christian Leth Christensen, Region centrala Danmark Anette Bjørn, Region södra Danmark

Susanne G. Sørensen, Region Nordjylland, Danmark Anya S. Midjord och Gudna á Rógvi Joensen, sjukhuset $L S H$, Färöarna

Isa-Maria Bergman, Motiva, Finland

Outi Kalske, Egentliga Finlands sjukvårdsdistrikt

Karólína Guðmundsdóttir, Landspítali -

Háskólasjúkrahús, Island

Trude Ertresvåg, Sykehuspartner HF, Norge

Kine Stjern och Evy Pleym, Sykehusinnkjøp HF, Norge
Anna Christiansson, Upphandlingsmyndigheten, Sverige

Anja Ekstrand och Sofie Areborn, Region Skåne,

Sverige

Jonna Bjuhr Männer, Koncernkontoret Region Västra

Götaland, Sverige

Christina Nukala-Pengel, Ålands hälso- och sjukvård, Åland

Rikke Dreyer och Lena Stenseng, Ecolabel Denmark

Weronika Rehnby, TEKO

Malin Hill, Berendsen AB

Hanne Selsholt Britz och Søren Vinzent, De Forenede

Dampvaskerier A/S

Fredrik Johansen, FOV Fabrics $A B$

Kate Riley, Oakdene Hollins

Rikke Fisher-Bogason och David Watson, PlanMiljø

Marie Pettersson och Daniel Eriksson, TEM

Birgitte Jørgensen Kjær och Anne-Mette Lysemose

Bendsen, Miljøstyrelsen

Frågor om guiden och nätverket kan skickas till Birgitte Jørgensen Kjær på den danska Miljöstyrelsen: bjk@mst.dk

\footnotetext{
${ }^{13}$ http://susproc.jrc.ec.europa.eu/textiles/docs/141222\%20EU\%20GPP\%2OTextiles_Technical\%2Obackground\%2Oreport_Draft\%20 version\%201.pdf
} 
Nordiska ministerrådet

Ved Stranden 18

DK-1061 Copenhagen K

www.norden.org

Denna guide riktar sig till upphandlare inom den nordiska hälso-och sjukvårdssektorn som ansvarar för inköp av textilprodukter och -service och hjälper dem att utveckla processer för att fastställa lämpliga och användbara miljökriterier i upphandlingsdokument. Upphandlare kan lära sig vilka aspekter av produktion och textilvård som får störst miljöpåverkan och hur dessa kan bemötas med olika kriterier. De kan lära sig mer om miljömärkningars roll vid upphandling och kan hitta länkar till färdiga kriterier och annan användbar information från nationella upphandlingsmyndigheter. Den här guiden har utvecklats i samarbete med ett nordiskt nätverk av upphandlare i hälso- och sjukvårdssektorn som ett led i ett initiativ inom den nordiska handlingsplanen för hållbart mode och textilier, "Nord en - välklädd i en ren miljö". Den finansieras av Nordiska ministerrådet. 